\title{
IMPLEMENTASI AMSAL 17:22 DI MASA PANDEMI COVID-19 SEBAGAI SATU CARA UNTUK MENAIKAN IMUN TUBUH
}

\author{
Timothius Nubatonis ${ }^{1}$, Alvyn Cesarianto Hendriks ${ }^{2}$ \\ Stimson Hutagalung ${ }^{3}$, Rolyana Ferinia ${ }^{4}$ \\ Magister Filsafat Universitas Advent Indonesia ${ }^{123}$ \\ Fakultas Ekonomi Universitas Advent Indonesia ${ }^{4}$ \\ timothius_nubatonis@yahoo.com
}

\begin{abstract}
During a pandemic, the body's immune system is very vital, because it is the body's immune system that plays a role in fighting viruses and helping the body recover. The heart and mind are very influential on the body's immune system. Proverbs 17:22 records that the human heart and mind are very influential. Based on this background, the purpose of this paper is to prove the truth of Proverbs 17:22 about a happy heart as a scientifically proven drug that can affect the body's immune system so that it can be implemented during the Covid-19 pandemic. The method used in this study is a qualitative method whose results are explained in a narrative manner with data collection techniques through literature study and the biblical text that is used as the basis will be interpreted using the hermeneutic method. The results obtained from this study are that the text of Proverbs 17:22 can be scientifically proven with the result that a happy heart, a good state of mind will increase the body's immune system so that it becomes the body's natural medicine, and vice versa a heart filled with sadness, stress will trigger a weakening of the immune system so that it is vulnerable. against disease. Thus the text of Proverbs 17:22 can be implemented or applied during the current Covid-19 pandemic.
\end{abstract}

Key Words: Proverbs 17:22, Covid-19, Immune

Abstrak. Di masa pandemi imun tubuh menjadi hal yang sangat vital, sebab imun tubuhlah yang berperan dalam melawan virus dan membantu pemulihan tubuh. Hati dan pikiran adalah hal yang sangat berpengaruh terhadap imun tubuh. Amsal 17:22 mencatat bahwa hati dan pikiran manusia sangat berpengaruh sekali. Berdasarkan latar belakang tersebut, maka tujuan penulisan ini adalah untuk membuktikan kebenaran dari Amsal 17:22 tentang hati yang gembira sebagai obat yang dibuktikan secara ilmiah yang dapat berpengaruh terhadap imun tubuh agar dapat diimplementasikan di masa pandemi Covid-19. Metode yang digunakan dalam penelitian ini metode kualitatif yang hasilnya diterangkan secara naratif dengan teknik pengumpulan data melalui studi pustaka dan teks Alkitab yang dijadikan landasan akan ditafsirkan menggunakan metode hermeneutic. Hasil yang didapat dari penelitian ini adalah teks Amsal 17:22 dapat dibuktikan secara ilmiah dengan hasil bahwa hati gembira, situasi pikiran yang baik akan meningkatkan imun tubuh sehingga menjadi obat alami tubuh, demikian sebaliknya hati yang dipenuhi kesedihan, stress akan memicu melemahnya imun sehingga rentan terhadap penyakit. Dengan demikian teks Amsal 17:22 dapat diimplementasikan atau diterapkan pada masa pandemic Covid-19 saat ini.

Kata Kunci: Amsal 17:22, Covid-19, Imun

Timothius Nubatonis, Alvyn C. Hendriks, Stimson Hutagalung, Rolyana Ferinia 260 
Pandemi memiliki pengertian suatu penyebaran penyakit atau wabah yang terjadi secara merata dan dalam lingkup yang sangat luas (Setiawan, 2021). Dari pengertian tersebut dapat dimengerti dengan jelas bahwa Covid19 disebut pandemi sebab terjadi secara merata dan luas bahkan secara global. Persebaran Covid-19 merata terjadi di seluruh dunia, termasuk di negara Indonesia yang menyebar secara merata di seluruh wilayah Indonesia.

Dampak dari pandemi Covid-19 yang dirasakan masyarakat sangat luas dan sangat membebani masyarakat (Tendean et al., 2021). Dampak yang ditimbulkan bukan hanya dalam bidang kesehatan saja, namun juga berdampak dalam bidang perekonomian baik secara nasional maupun secara global. Dari segi kesehatan sendiri yang berdampak langsung dari pandemi ini membuat masyarakat banyak yang sakit bahkan sampai meninggal dunia.

Data persebebaran kasus Covid-19 yang didapat dari situs resmi Satgas Covid-19 Indonesia pertanggal 4 Agustus 2021 didapati bahwa telah menyebar di 223 negara di dunia, yang terkonfirmasi positif secara global berjumlah 198.778 .175 , dan yang meninggal sejumlah 4.235.559. Sementara secara nasional data menunjukkan yang terkonfirmasi positif berjumlah 3.496.700, yang sudah sembuh sejumlah 2.873.669, dan sementara data yang meninggal berjumlah 98.889 (Satgas Covid-19, 2021). Tingkat kematian 
akibat Covid-19 di bulan Juli tahun 2021 ada kecenderungan merangkak naik sekitar 2,76\% (Salurante et al., 2021).

Secara sederhana proses kerja tubuh apabila ada benda asing masuk dalam tubuh, termasuk virus Covid-19, maka tubuh akan berusaha melindungi diri dari virus tersebut dengan membentuk pertahanan tubuh yang disebut imun atau kekebalan tubuh. System kerja imun tubuh pada tubuh manusia apabila ada benda asing masuk atau virus yang masuk, hal pertama kali adalah upaya untuk mengenali virus tersebut. Apabila sudah dapat dikenali dengan baik, maka tentara tubuh ini akan berusaha melawan dengan cara menahan dan menghancurkan virus atau benda asing yang masuk tersebut (Purnamasari, 2020).

Upaya-upaya pemerintah untuk pencegahan telah banyak dilakukan untuk mencegah virus ini menyebar lebih banyak lagi. Upaya-upaya itu antara lain dengan menerapkan peraturan karantina wilayah, pembatasan sosial berskala besar (PSBB), penerapan upaya untuk menjaga kebersihan diri dengan penerapan 3M, dan uapaya-upaya lain diusahakan namun sampai sekarang ini belum berhasil sepenuhnya. Ketika upaya-upaya sudah dilakukan namun belum berhasil sepenuhnya, maka satu hal yang bisa kita lakukan dalam diri tiap-tiap pribadi yang adalah salah satu cara pencegahan penyakit yang disebabkan Covid-19, yaitu dengan menjaga diri masingmasing untuk mempertahankan dan meningkatkan daya tahan atau imun tubuh.

Timothius Nubatonis, Alvyn C. Hendriks, Stimson Hutagalung, Rolyana Ferinia 262 
Stres atau tekanan dalam diri seseorang akan mempengaruhi imun tubuh seseorang (Haerussaleh, 2020). Stres akan berpengaruh terhadap turunnya imun tubuh manusia sebab ketika manusia mengalami stres hormon kortisol akan muncul yang akan membuat berkurangnya imun tubuh manusia (Dinsi, 2011). Sebaliknya, disaat hati gembira ini akan berpotensi meningkatnya daya tahan tubuh atau imun seseorang, sebab di saat hati gembira maka akan menjauhkan diri dari depresi yang menurunkan imun tubuh seseorang (Nurul Pujiastuti et al., 2021). Dalam hal ini, secara tidak langsung dapat kita mengerti bahwa hati yang gembira adalah sebuah obat yang dapat membantu mencegah penyakit akibat virus covid-19.

Jauh sebelum para ilmuwan meneliti tentang hati yang gembira, Kitab Amsal memberikan keterangan bahwa hati yang gembira adalah obat. "Hati yang gembira adalah obat yang manjur, tetapi semangat yang patah mengeringkan tulang" (Ams. 17:22). Dari ayat ini dapat dilihat bahwa ketika hati gembira akan menjadi sebuah obat, namun jika hati tidak gembira, mengalami stres akan memicu penyakit. Pertanyaannya adalah bagaiamanakah Amsal 17:22 yang ditulis jauh sebelum adanya pendemi dapat dibuktikan secara ilmiah sehingga bisa diimplementasi pada masa pandemi Covid-19 saat ini? Maka tujuan dari penelitian ini adalah menjawab pertanyaan yang muncul yaitu untuk membuktikan kebenaran dari Amsal 17:22 tentang hati yang gembira sebagai obat yang dibuktikan secara ilmiah 
yang dapat berpengaruh terhadap imun tubuh agar dapat diimplementasikan di masa pandemi Covid-19.

Amsal 17:22 disebutkan bahwa hati yang gembira adalah obat, sehingga perlu dibuktikan kebenaran pernyataan ayat ini dengan latar ilmiah, yaitu dengan menguraikan tentang proses terjadinya tersebut. Secara mendalam akan dilihat tentang hal-hal alami apa yang yang terjadi ada dalam tubuh sehingga bisa berdampak positif untuk menjadi obat sehingga dapat diimplementasikan di masa pandemi covid-19.

\section{METODE}

Dalam penelitian ini metode yang akan digunakan adalah metode penelitian kualitatif, di mana peneliti akan mencari tahu mengenai subyek yang diteliti dengan latar alamiah, bukan bentuk statistik yang kemudian akan

dievaluasi serta akan diterangkan secara naratif (Andrianta et al., 2020). Teknik pengumpulan data dengan cara studi pustaka, yaitu mengumpulkan data dari penelitian-penelitian sebelumnya dalam bentuk jurnal-jurnal ilmiah, artikel-artikel serta buku-buku yang terkait dengan penelitian. Sementara teks Alkitab akan digali pengertiannya dengan menggunakan sistem hermeneutic yaitu menggali pengertiannya dengan cara menerjemahkan atau menafsirkan teks tersebut berdasarkan konteks dan historisnya (Andrianta et al., 2020).

HASIL

Timothius Nubatonis, Alvyn C. Hendriks, Stimson Hutagalung, Rolyana Ferinia 264 
Amsal 17:22 yang ditulis ratusan tahun yang lalu dapat dibuktikan secara ilmiah dalam metode penelitian modern di masa ini. Irawati membuktikan dalam penelitiannya bahwa hati yang bersukacita berdampak positif pada kesehatan tubuh jika berlandaskan persekutuan dengan Allah. Pikiran yang penuh dengan tekanan sangat berpengaruh terhadap kesehatan jasmani (Irawati, 2020). Lebih jauh lagi Utami dalam penelitiannya memberikan gambaran pengaruh pikiran terhadap kesehatan jasmani, yaitu apabila seseorang mengalami stress yang berkelanjutan maka dalam tubuh manusia akan mengalami reaksi kimia yang berlebih sehingga akan sangat berbahaya apabila ini terjadi secara berkelanjutan yang konsekuensinya berdampak pada sistem kekebalan tubuh manusia, yang seharusnya rekasi kimia ini akan menguntungkan tubuh manusia, namun apabila berlebihan akan merugikan tubuh manusia (Utami, 2017).

Stres akan membuat imun tubuh melemah, sehingga akan memicu tubuh rentan terhadap penyakit, secara khusus kaitannya dengan penelitian ini maka tubuh rentan terinfeksi virus Covid-1(Utami, 2017). Sebaliknya, hati yang gembira akan memicu kekebalan tubuh atau imun meningkat,(Perkasa, 2020) sehingga akan menjadi obat alami yang akan membentengi dan melawan benda asing atau sel abnormal yang ada dalam tubuh, dalam hal ini maka hati yang gembira menjadi sebuah obat dari salah satu upaya pencegahan penyakit yang disebabkan virus Covid-19. Dengan demikian dapat terlihat dengan jelas implementasi dari teks Alkitab Amsal 17:22 hati Timothius Nubatonis, Alvyn C. Hendriks, Stimson Hutagalung, Rolyana Ferinia 265 
yang gembira sebagai obat, yaitu hati gembira memicu imun tubuh sebagai obat alamai virus Covid-19, sementara stres dalam hal ini dimengerti sebagai mengeringkan tulang akan memicu penurunan imun tubuh sehingga rentan penyakit, yaitu rentan terinfeksi virus Covid-19.

\section{PEMBAHASAN}

\section{Pandemi Covid-19}

Sejak Organisasi Kesehatan Dunia mengumumkan pada 11 Maret 2020, Penyakit Coronavirus atau lebih dikenal dengan sebutan Covid-19 telah menjadi pandemi global. Virus ini, Covid-19 pertama kali muncul di kota Wuhan, China pada akhir tahun 2019 (Agung, 2020). Perkembangan virus ini begitu sangat cepat, sehingga dalam penyebarannya dalam waktu yang tidak begitu lama virus ini sudah menyebar di seluruh dunia, termasuk di Indonesia. Oleh karena perkembangannya yang begitu cepat dan sangat luas bahkan berdampak global maka disebut sebagai pandemic seperti pengertian yang telah diuraikan sebelumnya.

\section{Covid-19}

Covid-19 merupakan suatu penyakit pernafasan akut yang disebabkan oleh virus corona (SAR-COV 2) yang merupakan sebuah jenis virus baru dan merupakan sebuah penyakit menular (Sari, 2020). Virus ini bisa ditularkan melalui setiap droplet yang keluar setiap seseorang sedang berbicara atau 
batuk atau juga pada saat bersin. Virus ini diketahui pertama kali di China, tepatnya di kota Wuhan pada bulan November tahun 2019 dan telah ditetapkan oleh WHO sebagai pandemi global. Ketika virus ini berada pada suatu lingkungan atau tempat yang mendukung perkembang biakannya, maka virus ini akan bertumbuh dengan cepat dengan cara membelah diri. Tempat yang memungkinkan virus ini berkembang dengan baik berada di mata, hidung, mulut atau pada jaringan tubuh yang lunak (Marzuki et al., 2021).

Masa inkubasi virus ini untuk menginfeksi manusia membutuhkan waktu sekitar 1 sampai 14 hari. Gejala klinis yang ditimbulkan apabila seseorang terinfeksi virus ini pada umumnya batuk kering, demam, hilangnya penciuman dan sesak nafas. Pada perkembangannya gejala klinis yang ditimbulkan oleh virus ini diantaranya mual, muntah, diare dan juga sakit kepala. Akibat fatal yang disebabkan oleh virus ini adalah terjadinya kematian, dan lebih sering kontributor yang menambah fatal adalah adanya komplikasi atau penyakit penyerta (Marzuki et al., 2021).

\section{Pencegahan}

Usaha pencegahan penularan dapat dilakukan dengan beberapa cara yang direkomendasikan baik WHO maupun pemerintah. Usaha pencegahan yang telah direkomendasikan itu antara lain mencuci tangan yang bersih dengan sabun, menjaga jarak, menerapkan etika batuk dan bersin dengan 
benar, menghindari kontak erat dengan orang yang bergejala atau orang yang positif terinfeksi (Moudy \& Syakurah, 2020). Masker haruslah selalu digunakan apabila sedang mengadakan kontak dengan orang lain, serta apabila tidak penting sekali diharapkan untuk tinggal di rumah.

Usaha pencegahan yang tidak kalah penting adalah dengan cara menghindari sentuhan pada mata, hidung, dan mulut. Ketika mau menyentuh bagian-bagian tubuh tersebut harus dipastikan bahwa tangan sudah bersih. Tangan yang tidak bersih maka akan beresiko menularkan penyakit yang disebabkan oleh Covid-19 yang menempel pada benda-benda tertentu yang kemudian disentuh oleh tangan dan menempel pada tangan tersebut (Siregar et al., 2020).

\section{Gejala}

Orang yang terinfeksi dengan virus Covid-19 ada yang menunjukkan gejala-gejala khusus namun ada juga yang tidak menunjukkan gejala-gejala yang disebut sebagai OTG. Orang yang terinfeksi dan kondisi tubuhnya kurang kuat atau bahkan ke arah lemah maka akan menunjukkan serangkaian gejala-gejala. Gejala yang umum dank has pada pasien penderita Covid-19 adalah batuk, Flu, demam dan sesak nafas (Siregar et al., 2020). Namun pada perkembangan penyakit ini menunjukkan gejala yang berbeda-beda dan bukan lagi hanya sekedar batuk, flu, demam dan sesak nafas, melainkan tanda dan gejalanya bervareasi menurut serangan virus di 
mana terjadi. Tanda dan gejala itu antar alain terjadinya gangguan pencernaan yang bisa menyebabkan diare, sakit kepala, konjungtivitis atau mata memerah yang disebabkan infeksi pada mata, hilangnya kemampuan untuk mengecap rasa, tidak bisa untuk mencium bau dan tidak jarang terjadi ruam atau bentol-bentol pada kulit yang mirip orang yang sedang mengalami gangguan karena alergi (Marzuki et al., 2021).

\section{Imun Tubuh}

Imun tubuh adalah system pertahanan atau daya tahan alami yang dimiliki oleh tubuh manusia yang fungsinya mempertahankan, menyerang dan menetralisir apabila ada benda asing yang masuk dalam tubuh manusia, khususnya apbila ada infeksi. Imunitas akan terganggu apabila manusia mengalami sebuah tekanan yang mengakibatkan rasa cemas atau stres (Gumantan et al., 2020). Hal ini juga berlaku atau terjadi apabila orang yang terinfeksi Covid-19 dan kemudian merasakan ketakutan yang berlebihan sehingga menimbulkan rasa cemas dan stress maka akan mengakibatkan system imun akan tidak efektif melawan virus yang masuk, akibatnya akan susah untuk melawan virus yang masuk sehingga penyembuhan akan berlangsung lama bahkan bisa mengakibatkan suatu akibat yang fatal sampai pada kematian.

Orang yang mengalami kecemasan yang mengakibatkan stres, maka tubuh akan merespon dengan cara hypothalamus yang ada pada tubuh akan 
mengeluarkan Corticotropin Releasing Hormone ( $\mathrm{CRH})$. Kemudian yang terjadi berikutnya $\mathrm{CRH}$ ini memicu kelenjar pituitary untuk mengeluarkan Adreno Corticotropin Releasing Hormone (ACTH), kelenjar Adrenal inilah yang kemudian melepaskan hormon Kortisol (Subrata et al., 2020). Hormon Kortisol yang berlebihan inilah yang dapat menganggu system imun tubuh manusia dalam upaya melawan benda-benda asing atau virus-virus yang masuk kedalam tubuh manusia. Imun tubuh manusia akan menjadi lemah, sehingga apabila virus Covid-19 menginfeksi manusia, maka akan menyulitkan system imun melawan virus tersebut.

Sebaliknya, management stres yang baik akan berpengaruh besar terhadap system imun manusia. Hati yang gembira merupakan hasil dari management stres akan memiliki manfaat yang baik yaitu meningkatkan imun tubuh dan hal ini berbanding terbalik situasinya pada saat mengalami stres. Ketika dapat mengelola stres dengan baik, tubuh akan memproduksi empat hormon, yang lebih dikenal dengan sebutan "Hormon bahagia." Hormonhormon tersebut adalah Dopamin, Serotonin, Oksitosin dan Endorfin (Fadli, 2021). Keempat hormon ini akan saling bekerjasama untuk membuat system kerja tubuh menjadi lebih baik yaitu system otak, pencernaan, anti nyeri alami, anti stres dan system-sistem lainnya, sehingga akan merangsang system imun bekerja dengan baik, hasilnya system imun akan meningkat dan akan bekerja optimal melawan virus, bakteri atau benda asing yang masuk kedalam tubuh manusia (Wibowo, 2018).

Timothius Nubatonis, Alvyn C. Hendriks, Stimson Hutagalung, Rolyana Ferinia 270




\section{Imun dan Covid-19}

Sifat virus adalah menyerang system imun tubuh untuk melemahkan pertahanan, termasuk juga sifat dari virus Covid-19 adalah menyerang system imun tubuh manusia yang terinfeksi (Nurlila \& La Fua, 2020). Oleh sebab itu, system imun menjadi sesuatu yang sangat penting bahkan menjadi suatu faktor yang utama dalam menghadapi virus Covid-19 karena sampai saat ini belum ditemukan obatnya (Mustofa \& Suhartatik, 2020). Oleh sebab itu di masa pandemi Covid-19 ini sangat diperlukan sekali menjaga imun tubuh. Salah satu hal untuk menjaga imun tubuh tetap stabil dan baik maka diperlukan suatu suasana hati yang tenang, bahagia, gembira dan memiliki pikiran yang positif untuk memunculkan hormon-hormon yang membuat system imun bekerja dengan baik, sehingga dapat melawan virus dengan baik.

\section{Amsal 17:22}

Teks Amsal 17:22 berisi suatu kata bijak, yaitu, "Hati yang gembira adalah obat yang manjur, tetapi semangat yang patah mengeringkan tulang." Kekuatan akan firman Sang Pencipta, Tuhan Allah sangat berkuasa,(Hutagalung \& Ferinia, 2020) sehingga menurut ayat ini yang telah ditulis ratusan tahun yang lalu, dapat dimengerti bahwa sebuah kesehatan dapat dipengaruhi dari hal-hal internal manusia, yaitu suatu perasaan dan sikap hati, yang tentunya mengarah kepada Sang Pencipta. Dalam bagian ini 
akan diuraikan dan dilihat dari segi alkitabiah mengenai sebuah pengaruh suasana hati terhadap kesehatan fisik manusia.

\section{Sekilas Tentang Kitab Amsal}

Dalam bahasa Ibrani, kata Amsal berasal dari kata mashall, yang berarti peribahasa, selain mengandung arti peribahasa. Arti lainnya bisa juga merujuk pada orang bijak, perumpamaan, behkan arti yang lebih jauh bisa juga berarti peribahasa hikmat (Irawati, 2020). Kitab Amsal banyak memuat kata-kata bijak yang mengandung berbagai hikmat yang hampir seluruh kitab Amsal ditulis oleh Raja Salomo, raja yang terkenal dengan penuh hikmat. Ada dua nama yang disebutkan dalam kitab Amsal yang juga terlibat dalam penulisan kitab Amsal ini, yaitu Agur bin Yake dan Lemuel. "Perkataan Agur bin Yake dari Masa. Tutur kata orang itu: Aku berlelah-lelah, ya Allah, aku berlelah-lelah, sampai habis tenagaku" (Ams. 30:1). "Inilah perkataan Lemuel, raja Masa, yang diajarkan ibunya kepadanya" (Ams. 31:1).

Dalam kitab Amsal 1:2-6 dengan jelas memberikan keterangan mengenai tujuan dari kitab Amsal, yaitu untuk memberikan dan mengetahui tentang hikmat dan kebijaksanaan, untuk bertumbuh dalam keadilan, jujur dan kebenaran, untuk lebih berpengetahuan, berilmu dan cerdas dalam pendidikan, yang jelas mengajarkan untuk hidup takut akan Tuhan sebab permulaan dari segala hal pengetahuan dan hikmat adalah takut akan Tuhan (Ams. 1:7).

Timothius Nubatonis, Alvyn C. Hendriks, Stimson Hutagalung, Rolyana Ferinia 272 
Secara umum, tentang literatur kebijaksanaan dalam tradisi Yahudi, termasuk kitab Amsal, tidak ada hubungannya dengan sejarah Israel. Jadi di sini, dalam kitab Amsal tidak mengatakan atau berkisah mengenai hal-hal besar tentang Tuhan dalam sejarah Israel. Yang penting dalam buku ini adalah bagaimana seseorang bisa hidup dengan garis lurus sesuai dengan aturan dan orang-orang saleh hidup sejalan dengan kehendak Tuhan. Katakata bijak yang terdapat dalam kitab Amsal memiliki pandangan kebijaksanaan yang sama dengan pandangan kebijakan umum di dunia kuno, akan tetapi ada perberbedaan dengan bangsa -bangsa lain mengenai prinsip dan sumber kebikasanaa tersebut, yaitu kitab Amsal menyatakan dengan jelas bahwa sumber kebijaksanaan adalah Tuhan (Adoe \& Sembodo, 2021).

\section{Exegesis Amsal 17:22}

Teks Amsal 17:22 yang isinya "Hati yang gembira adalah obat yang manjur, tetapi semangat yang patah mengeringkan tulang." Jelas memberikan gambaran suatu hubungan sebab akibat. Jika hati yang gembira dimiliki maka akan menjadi sebuah obat yang manjur dalam diri, namun sebaliknya jika suasana hati yang tidak semangat, dalam hal ini digambarkan sebagai hati yang patah akan menjadikan sebuah penyakit, yang dalam teks ini di terangkan sebagai keringnya tulang.

Timothius Nubatonis, Alvyn C. Hendriks, Stimson Hutagalung, Rolyana Ferinia 273 
Perbandingan dari beberapa terjemahan Alkitab akan memberikan gambaran yang lebih jelas mengenai maksud dari teks Amsal 17:22. Alkitab terjemaham Bahasa Indonesia Sehari-hari (BIS) dengan bahasa yang sederhana memberikan gembaran "Hati yang gembira menyehatkan badan; hati yang murung mematahkan semangat." Alkitab terjemahan Versi Mudah Dibaca (VMD) memberikan penjelasan "Sukacita adalah obat yang baik, tetapi dukacita adalah penyakit." Alkitab terjemahan Firman Allah Yang Hidup (FAYH) memberikan gambaran tentang teks ini dengan keterangan "Hati yang gembira bagaikan obat yang manjur, tetapi semangat yang patah membuat orang sakit." Dari beberapa terjemahan Alkitab memberikan sebuah petunjuk dan penjelasan bahwa semangat yang patah yaitu duka cita, kemurungan yang dalam hal ini adalah kesedihan memiliki pengaruh terhadap kesehatan manusia, pengaruh yang negatif yang bisa membuat manusia sakit. Sebaliknya, hati yang gembira, hati yang penuh sukacita akan mempengaruhi kesehatan seseorang ke arah positif, yaitu tetap terjaga kesehatannya dan apabila sakit bisa mempengaruhi terhadap kesembuhannya yang digambarkan sebagai sebuah obat yang manjur.

Ada dua kata kunci yang perlu dimengerti untuk memahami sepenuhnya dari teks Amsal 17:22, yaitu, kata "hati" dan "semangat". Kata hati dalam teks Amsal 17:22 berasal dari bahasa asli Alkitab yaitu לִ (lêb) selain memiliki terjemahan sebagai hati, kata ini juga diterjemahkan sebagai

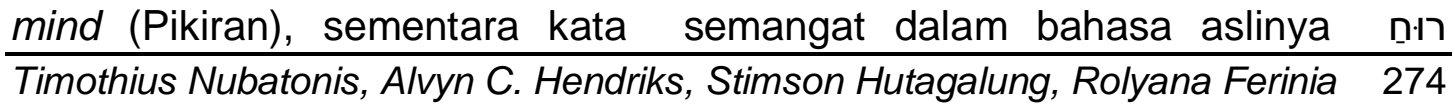


(rûach) yang dalam kitab Terjemahan Baru dituliskan sebagai semangat, namun pengertian dari bahasa aslinya bukan hanya sekedar semangat, tetapi juga bisa dimengerti sebagai pikiran (Meyers, 2021). Jadi dua kata kunci dalam teks ini yaitu hati dan semangat dua-duanya bisa diterjemahkan sebagai pikiran, sehingga dengan demikian masalah hati dan semangat berhubungan erat dengan pikiran.

Kata gembira dan frase mengeringkan tulang yang dalam terjemahan lain kesedihan atau duka cita adalah menggambarkan dan menunjukkan dengan jelas sebuah situasi atau keadaan dari suasana hati atau pikiran. Apabila dilihat dari pengertian yang lebih mendalam dari bahasa aslinya, yaitu Ibrani maka akan ditemukan situasi atau keadaan dari pikiran tersebut. Kata gembira berasal dari akar kata שָׁ (śâmach) yang artinya to brighten up (Untuk mencerahkan), gleesome (riang, gembira, sukacita), dengan demikian situasi atau keadaannya adalah cerah dan riang gembira. Mengeringkan tulang atau kesedihan dalam bahasa aslinya berakar dari kata गָ (nâkâ') yang memiliki arti viler (buruk, keji, hina) (Meyers, 2021), dengan demikian dalam pemahaman yang lebih dalam bahwa dukacita, sedih atau tulang yang kering dimengerti sebagai situasi atau keadaan pikiran yang sedang buruk, bisa dikatakan pikirannya kacau.

Melihat Amsal 17:22 dari perbandingan berbagai terjemahan Alkitab dan menguraikannya kata perkata dari bahasa aslinya, maka dapat dibaca dengan pengertian yang lebih luas sebagai berikut, "Ketika situasi hati Timothius Nubatonis, Alvyn C. Hendriks, Stimson Hutagalung, Rolyana Ferinia 275 
gembira, yang adalah pikiran cerah merupakan sebuah obat yang mujarab, yang menyembuhkan, akan tetapi apabila situasi hati sedih, dukacita atau kondisi pikiran sedang buruk, kacau akan melemahkan tubuh yaitu menyebabkan penyakit."

Implikasi teoritis yang ada dalam penulisan ini, teori dalam Amsal 17:22 terbukti melalui riset ilmiah yaitu tingkat imun seseorang dapat dipengaruhi dari situasi pikiran, situasi pikiran baik maka imun akan meningkat menjadi baik, demikian sebaliknya. Secara praktis memiliki implikasi: (1) Bagi gembala hasil penelitian ini dapat dikhotbahkan dalam ibadah sebagai kabar sukacita akan keajaiban Tuhan; (2) Jemaat dapat mempraktekkannya dalam kehidupan sehari-hari sehingga menjadi kesaksian yang dapat menguatkan; (3) Bagi gembala jemaat akan menjadi bahan dasar yang menarik ketika memberikan konseling apabila ada anggota jemaat yang mengalami masalah yang mirip; (4) Dengan penelitian ini juga dapat digunakan sebagai bahan-bahan seminar kesehatan; (5) Menjadi sarana atau jembatan dalam konteks penginjilan, sebab pemahaman kesehatan bisa menembus berbagai lini.

\section{KESIMPULAN}

Dari analisa Amsal 17:22 didapati bahwa ada kaitan yang erat antara kesehatan dengan pikiran. Dari berbagai terjemahan Alkitab dan analisa kata-kata dari bahasa aslinya didapati bahwa situasi pikiran yang baik, 
bersifat positif dengan ditunjukkan dalam situasi hati gembira akan berpengaruh terhadap kesehatan yaitu menjaga tubuh tetap sehat bahkan dalam keadaan tubuh lemah atau sakit bisa menjadi suatu pemicu proses kesembuhan. Namun sebaliknya, apabila pikiran dalam kondisi tidak baik akan berdampak terhadap kesehatan, dalam hal ini memicu sakit.

Secara ilmiah Amsal 17:22 dapat dibuktikan dengan ssstem kerja hormon dalam tubuh manusia. Apabila orang dalam situasi gembira, bahagia maka akan mempengaruhi empat hormon dalam tubuh yaitu Dopamin, Serotonin, Oksitosin dan Endorfin yang akan memicu imun tubuh akan naik, menjadi benteng pertahanan dan obat alami dalam tubuh untuk mengalahkan penyakit. Sebaliknya apabila pikiran dalam situasi kacau, stress dan penuh tekanan maka akan mendorong hormon kortisol diproduksi berlebihan yang akan membuat system imun menurun, sehingga melemahkan tubuh dan rentan terhadap penyakit.

Dengan demikian hati yang gembira menurut Amsal 17:22 dapat diimplementasikan atau diterapkan bahkan dianjurkan dalam masa pandemi Covid-19, sebab sistem kerja penyakit yang disebabkan oleh virus Covid-19 adalah menyerang imun tubuh manusia. Maka dibutuhkan sekali imun yang kuat untuk menjaga tubuh tetap kuat, sehingga apabila virus menyerang akan dapat dilawan dengan imun yang kuat. Hati yang gembira adalah pendorong untuk membentuk dan menghasilkan imun kuat.

Timothius Nubatonis, Alvyn C. Hendriks, Stimson Hutagalung, Rolyana Ferinia 277 


\section{DAFTAR PUSTAKA}

Adoe, Y. S., \& Sembodo, J. (2021). Peranan Keluarga Menurut Amsal 22:6 Dalam Pembentukan Karakter Anak. Miktab: Jurnal Teologi dan Pelayanan Kristiani, 1(1), 52-61.

Agung, I. M. (2020). Memahami Pandemi Covid-19 Dalam Perspektif Psikologi Sosial. Psikobuletin:Buletin IImiah Psikologi, 1(2), 68-84.

Andrianta, D., Hutagalung, S., \& Ferinia, R. (2020). Kontekstualisasi lbadah Penghiburan pada Tradisi Slametan Orang Meninggal Dalam Budaya Jawa. VISIO DEI: Jurnal Teologi Kristen, 2(2), 244-264. https://doi.org/10.35909/visiodei.v2i2.163

Dinsi, V. (2011). Jangan Mau seumur Hidup Jadi Orang susah. Penerbit PT. Alex Media Komputindo Kompas Gramedia.

Fadli, R. (2021). Mengenal 4 Jenis Hormon untuk Mental Yang Sehat. halodoc.

Gumantan, A., Mahfud, I., \& Yuliandra, R. (2020). Tingkat Kecemasan Seseorang Terhadap Pemberlakuan New Normal Dan Pengetahuan Terhadap Imunitas Tubuh. Sport Science and Education Journal, 1(2), 18-27. https://doi.org/10.33365/ssej.v1i2.718

Haerussaleh. (2020). Merdeka Berpikir "catatan Harian Pandemi Covid-19." Unitomo Press.

Hutagalung, S., \& Ferinia, R. (2020). Menjelajahi Spiritualitas Milenial: Apakah Membaca Alkitab, Berdoa, dan Menghormati Acara di Gereja Menurun? Jurnal Teruna Bhakti, 2(2), 97-111. https://doi.org/10.47131/jtb.v2i2.50

Irawati, F. (2020). Dampak Hati yang Gembira Terhadap Kesehatan Jasmani : Eksposisi Amsal 17:22. Logia: Jurnal Teologi Pentakosta, 1(2), 110-123. https://doi.org/10.37731/log.v1i2.41

Marzuki, I., Bachtiar, E., Zuhriyatun, F., Purba, A. M. V., Kurniasih, H., Purba, D. H., Chamidah, D., Jamaludin, Purba, B., Puspita, R., Chaerul, M., Basmar, E., Sianturi, E., Suleman, A. R., Nasrullah, Hastuti, P., Mastutie, F., Purba, S., Rahmadana, M. F., \& Airlangga, E. (2021). Covid-19: Seribu Satu Wajah. Yayasan Kita Menulis.

Meyers, R. (2021). E-Sword. Yayasan Lembaga SABDA.

Moudy, J., \& Syakurah, R. A. (2020). Pengetahuan terkait usaha pencegahan Coronavirus Disease (COVID-19) di Indonesia. Higeia Journal of Public Health Research and Development, 4(3), 333-346. 
https://doi.org/10.15294/higeia.v4i3.37844

Mustofa, A., \& Suhartatik, N. (2020). Meningkatkan Imunitas Tubuh Dalam Menghadapi Pandemi Covid-19 Di Karangtaruna Kedunggupit, Sidoharjo, Wonogiri, Jawa Tengah. SELAPARANG Jurnal Pengabdian Masyarakat Berkemajuan, 4(1), 324-332. https://doi.org/10.31764/jpmb.v4i1.3100

Nurlila, R. U., \& La Fua, J. (2020). Jahe Peningkat Sistem Imun Tubuh di Era Pandemi Covid- 19 di Kelurahan Kadia Kota Kendari. Jurnal Mandala Pengabdian Masyarakat, 1(2), 54-61. https://doi.org/10.35311/jmpm.v1i2.12

Nurul Pujiastuti et al. (2021). Tetap Kreatif dan Inovatif di Tengah Pandemi Covid-19. PT. Nasya Expanding Management.

Perkasa, G. (2020). Apakah Rasa Bahagia Tingkatkan Kekebalan Tubuh? Kompas.

Purnamasari, A. (2020). Sistem Pertahanan Tubuh. In Modul Pembelajaran SMA Biologi (hal. 1-28). Kementrian Pendidikan Dan Kebudayaan.

Salurante, T., Tioma Silaen, R., Keluanan, Y., \& Belo, Y. (2021). TANGGUNG JAWAB MENJALANKAN PROTOKOL KESEHATAN DI TENGAH PANDEMI COVID-19 DITINJAU DARI PERSPEKTIF ETIKA KRISTEN. VISIO DEI: JURNAL TEOLOGI KRISTEN, 3(1), 63-83. https://doi.org/10.35909/VISIODEI.V311.198

Sari, M. K. (2020). Sosialisasi tentang Pencegahan Covid-19 di Kalangan Siswa Sekolah Dasar di SD Minggiran 2 Kecamatan Papar Kabupaten Kediri. Jurnal Karya Abdi, 4(1), 80-83.

https://doi.org/10.22437/jkam.v4i1.9821

Satgas Covid-19. (2021). Data Persebaran Covid-19 Di Indonesia. Komite Penanganan Covid-19 dan Pemulihan Ekonomi Nasional (KPCPEN).

Setiawan, E. (2021). Kamus Besar Bahasa Indonesia (KBBI). KBBI Online.

Siregar, R., Gulo, A. R. B., \& Sinurat, L. R. E. (2020). Edukasi Tentang Upaya Pencegahan Covid-19 Pada Masyarakat Di Pasar Sukaramai Kecamatan Medan Area Tahun 2020. Jurnal Abdimas Mutiara, 1(2), 191-198.

Subrata, T., Masyeni, S., Lestarini, A., Udiyani, D. P. C., Sari, N. L. P. E. K., \& Permana, S. P. (2020). Berlayar Melintasi Badai Covid-19: jaga Kondisi Tanpa Mengabaikan Proteksi. Warmadewa University Press.

Tendean, J. J., Nainggolan, B. D., \& Hutagalung, S. (2021). Pandemic Covid19, Health Literature and Great Commission Pandemi Covid - 19, Literatur Kesehatan dan Amanat Agung. Grafta: Journal Of Christian 
Religion Education And Biblical Studies, 1(1), 1-11.

Utami, T. N. (2017). Tinjauan Literatur Mekanisme Zikir Terhadap Kesehatan: Respons Imunitas. Jurnal JUMANTIK, 2(1), 100-110. https://doi.org/10.30829/jumantik.v2i1.965

Wibowo, I. (2018). Seperti Ini Reaksi yang Terjadi Pada Tubuh Saat Merasa Bahagia. Womantalk. 